\title{
MINERALOGY OF DIAMONDS FROM THE JUINA PROVINCE, BRAZIL
}

\author{
Débora P. Araújo ${ }^{1}$, José C. Gaspar', Yingwei Fei ${ }^{2}$, Erik H. Hauri ${ }^{3}$, Russell Hemley ${ }^{2}$ and \\ Galina Bulanova ${ }^{4}$ \\ ${ }^{1}$ Universidade de Brasilia, Brazil; ${ }^{2}$ GL, Carnegie Institution of Washington, USA $;{ }^{3}$ DTM, Carnegie Institution of \\ Washington, USA; ${ }^{4}$ University of Bristol, $U K$
}

\section{INTRODUCTION}

The Juina Kimberlite Province at the SW border of the Amazon Craton, Brazil (Figure 1), is a well-known site for deep diamonds originated in the transition zone (TZ) and lower mantle (LM). They have been recovered from the São Luiz River (Wilding et al. 1991, Harte and Harris 1994, Hutchison 1997) and other local drainages (Kaminsky et al. 2001). The Province intrudes the Rio Negro-Juruena Mobile Belt (1,8-1,5 Ga; Figure 1). Rb/Sr (kimberlite mica and whole rock; Bizzi, 1993) and U/Pb (kimberlitic breccia zircons; Heaman et al. 1998) methods yield ages of 198 and 92-95 Ma, respectively, for the Juina Province.

Our results reinforce the deep origin for alluvial diamonds from the Juina Province and allow us to expand this interpretation for most primary and alluvial diamonds. They also contribute with new data to the understanding of this important occurrence.

\section{METHODS}

Methods used in this study were cathodoluminescence (CL), infrared spectroscopy (IR), carbon and nitrogen isotopes and $\mathrm{N}$ content measurements by secondary ion mass spectroscopy (SIMS). 188 primary diamonds from 3 kimberlites and 46 alluvial specimens from the rivers São Luiz (10), Duas Barras (8), Porcão (8) and Cinta Larga (20) were examined. CL images were obtained from 128 pieces of diamonds and 32 plates using an ELM-3R Nuclide Corporation luminoscope at the Geoscience Institute of the University of São Paulo and at the Department of Mineral Science of the Smithsonian Institution (SI). CL images from both sides of the plates were generated in order to check for matching features for further IR investigation. All diamonds were measured for IR using a microFTIR Bio Radius Excalibur espectrometer (60 to $440 \mu \mathrm{m})$ at the SI. IR traverses of 4 plates were performed at the National Synchrontron Light Source at the Brookhaven National Laboratory. The synchrontron source yielded high quality spectra with spatial resolution of $15 \mu \mathrm{m}$. C and $\mathrm{N}$ isotopic and $\mathrm{N}$ content in situ variation for 20 diamonds were measured through SIMS at the Department of Terrestrial Magnetism of the Carnegie Institution of Washington. The methods used are detailed elsewhere (Araujo 2002).

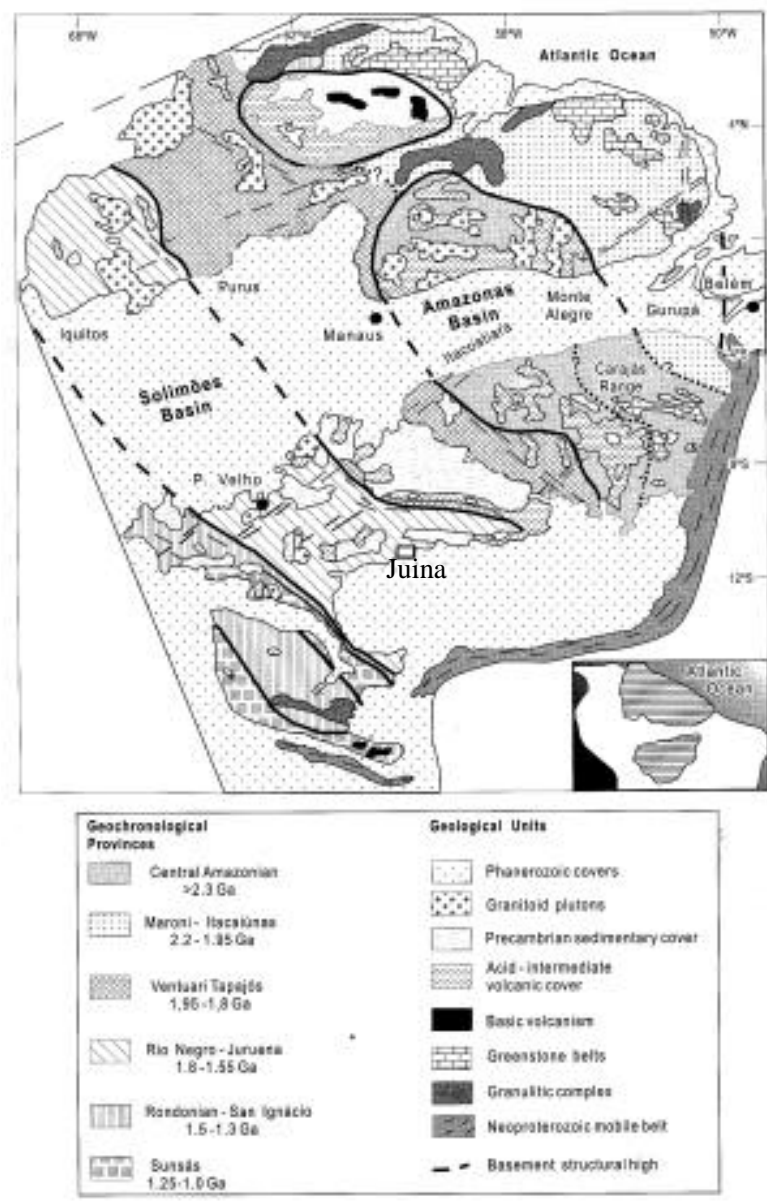

Figure 1 - Major geochronological provinces and main lithological associations of the Amazon Craton (Tassinari et al. 2000). The Juina Kimberlite Province is depicted by the rectangle. 


\section{RESULTS}

Diamonds are mostly resorbed fragments, tetraexaedroid and irregular, though regular octahedral and macles are described. Primary and alluvial diamonds could not be distinguished according to their morphological characteristics. CL images for most part of the diamonds present typical blue-sky color, but with low intensity. Most stones exhibit homogeneous CL patterns. Rare internal features were observed, which were octahedral growth zones, step-wise growth, truncated growth zones and fine parallel lines, the later two features being evidence for resorption and deformational processes. An example is depicted in Figure 2. Resorption after-growth features, revealed both by binocular loupe and CL investigation, are common amongst the Juina diamonds.

Type II diamonds ( $\mathrm{N}$-free) predominate among alluvial and primary stones (82\%). The minority Type I diamonds present low-N content (up to $\sim 300$ at. ppm, except for one specimen with 613 at. ppm of N-SIMS determination) and were classified as IaAB (24 stones) and $\mathrm{IaB}$ (6 stones). Except for three stones, IaAB diamonds are highly aggregated (> 90\%). The abundance of Type II stones agrees with the high number of low intensity CL diamonds.

$\ddot{a}^{13} \mathrm{C}$ for Type II diamonds varies from -3 to $-26.3 \%$ o and for Type I from -3.4 to $-13.8 \%$. The $\ddot{a}^{15} \mathrm{~N}$ interval for Type I diamonds ranges from +2.2 to $14.0 \%$ and the $\mathrm{N}$ content, from 3.85 to 613.74 at. ppm.

The Internal chemical variation was measured for $\mathrm{N}$ content (4 stones; IR-synchrontron and SIMS) and for $\mathrm{C}$ and $\mathrm{N}$ isotopes (6 stones; SIMS). One example, as depicted in Figure 2, is an IaAB octahedral diamond which showed CL matching features on both sides of the plate. $\mathrm{N}$ determinations are similar comparing both methods and $\mathrm{N}$ is highly aggregated all over the stone (97,7-100\%). $\ddot{a}^{13} \mathrm{C}$ and $\ddot{a}^{15} \mathrm{~N}$ variation for this specimen is ilustrated bellow (Figure 2B). As happens for most stones, $\ddot{a}^{13} \mathrm{C}$ shows a monotonous trend compared to the high variation of $\ddot{a}^{15} \mathrm{~N}$ through the diamond ( -14 to $-2,9 \%$ o for this specimen).

\section{DISCUSSIONS AND CONCLUSIONS}

$\ddot{a}^{13} \mathrm{C}$ data for Type I and Type II diamonds (this study) are compared in Figure 3 with those for worldwide upper mantle assemblages (Cartigny et al.1999, bars bellow the diagram) and to deep diamonds from Juina (Hutchison 1997 and Kaminsky et al. 2001) and from worldwide occurrences: Koffiefontein, Jagersfontein (Deines et al. 1991), Guinea (Hutchison 1997) and Lac de Gras (Davies et al. 1999). Our results suggest the existence of four sets of data concentrated near $-5 \%$; $13 \%$; $-18 \%$ and $-25 \%$, where Type I dia monds belong only to the first two groups. We, therefore, do not exclude the possibility that blanks in this interval could be attributed to lack of sampling.
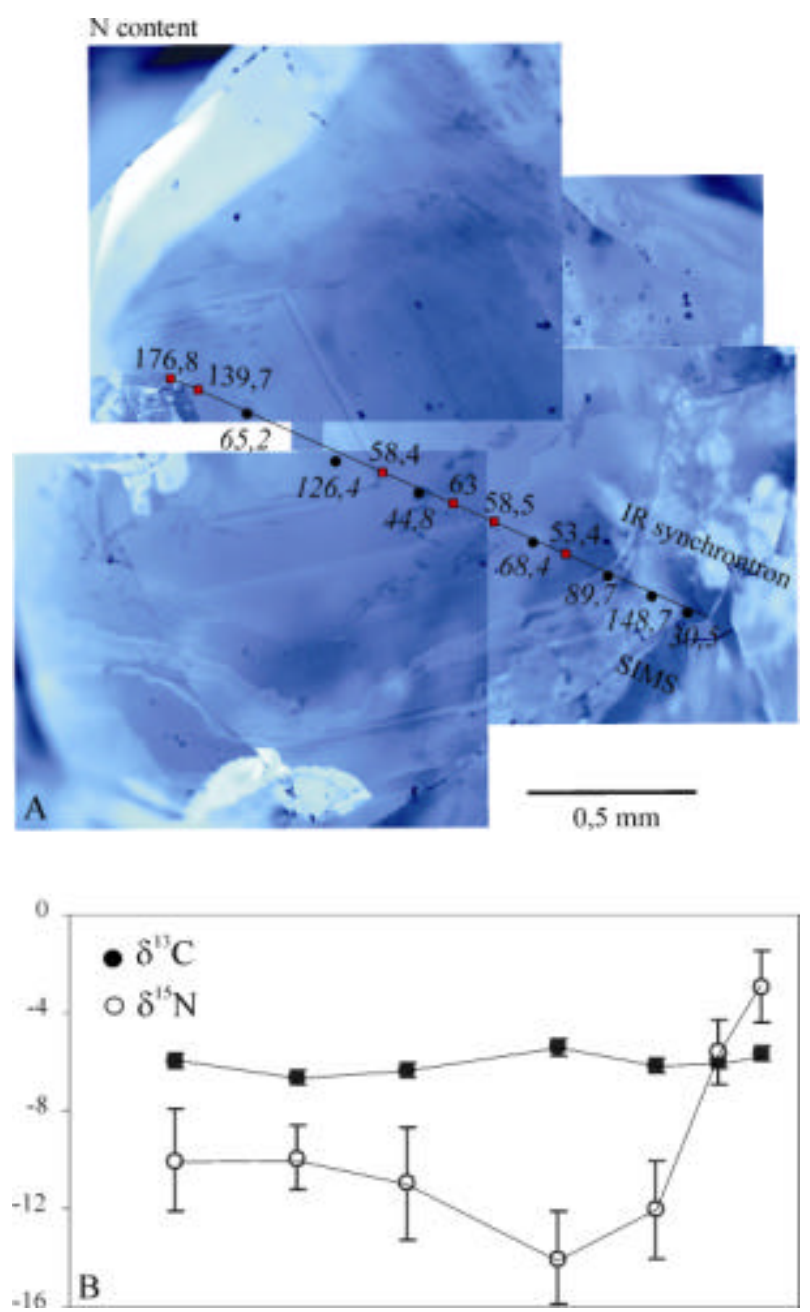

Figure 2 - A) Mosaic depicting CL image of a resorbed octahedral diamond (TR2-3). The values correspond to $\mathrm{N}$ content measured by SIMS (black dots, values in italic under the line) and by IR synchrontron source (red squares, values above the line, $15 \mu \mathrm{m}$ spatial resolution). $\mathrm{N}$ content measured by both methods are similar. Note the low $\mathrm{N}$ content $(65,2$ at. Ppm, first black circle on the left) measured in a dark region, which is probably the center of the stone. B) $\ddot{a}^{13} \mathrm{C}$ (black circle) and $\delta^{15} \mathrm{~N}$ (open circle) variation. The transverse correspond to SIMS determinations (black circles) in A.

The $\ddot{a}^{13} \mathrm{C}$ interval obtained here is expanded toward lighter values if compared to previous results: 
Hutchison (1997) and Kaminsky et al. (2001) observed two sets of data, one distributed near $-5 \%$ and other in the approximate interval between -11 to $-13 \%$. Transition zone (TZ) diamonds have been related to both groups while lower mantle (LM) diamonds concentrate around $-5 \%$, indicating the homogeneous carbon isotopic character of the LM (Hutchison 1997 and Kaminsky et al. 2001). Data for world wide LM diamonds also cluster around $-5 \%$ while $\mathrm{TZ}$ diamonds from Jagersfontien are in the interval between -20 to 25\%o (Deines et al. 1991).

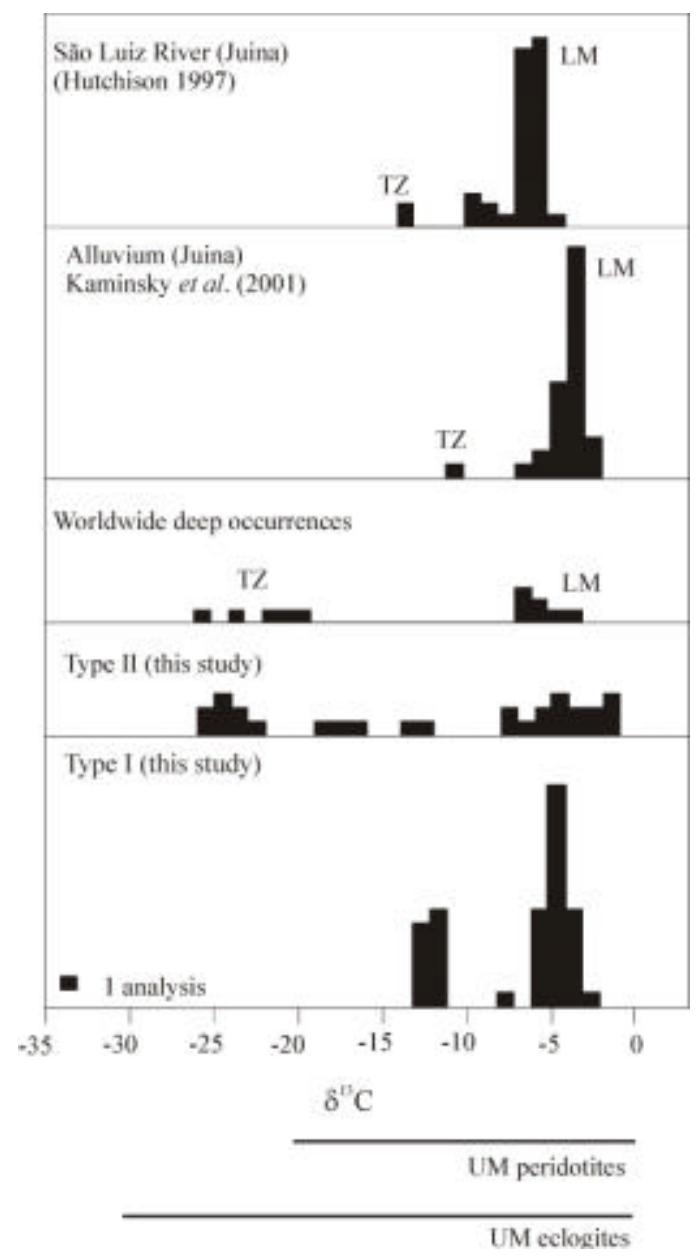

Figure 3 - $\ddot{a}^{13} \mathrm{C}$ composition of diamonds from the transition zone (TZ) and lower mantle (LM) from the Juina Kimberlite Province (Hutchison, 1997 and Kaminsky et al. 2001), of TZ and LM worldwide diamond occurrences (see text for locations and references) and from Type I and Type II stones studied here. Upper mantle (UM) peridotite and eclogite diamond $\ddot{a}^{13} \mathrm{C}$ compositions (Cartigny et al. 1999) are indicated by the bars bellow the diagram for comparison.
The $\ddot{a}^{15} \mathrm{~N}$ composition for the Juina diamonds $(+2 ., 2$ to $-14 ., 0 \%$ ) encloses previous results from Hutchison et al. (1999), that reported $-5.2 \%$ and $-6 \%$ for LM stones and $+1.3 \%$ and $+1.2 \%$ for $\mathrm{TZ}$ diamonds. Ample compositional intervals were observed here for single diamonds (e.g. -14 to $-2.9 \%$ and $-9.6 \%$ to $+2.2 \%$ ), and are within the composicional range for $\ddot{a}^{15} \mathrm{~N}$ data for worldwide diamond occurrences, as seen in Figure 4. Ample intervals have also been reported for diamonds from Mir and Udachynaya, Russia (Hauri et al. 1999; Figure 4). The ample $\ddot{a}^{15} \mathrm{~N}$ variation for single stones and the observed oscillatory patterns suggest the high sensibility of the nitrogen isotopic system in diamonds. Taking it into account, one may be caution when using positive $\ddot{a}^{15} \mathrm{~N}$ to trace re-cycled carbon.

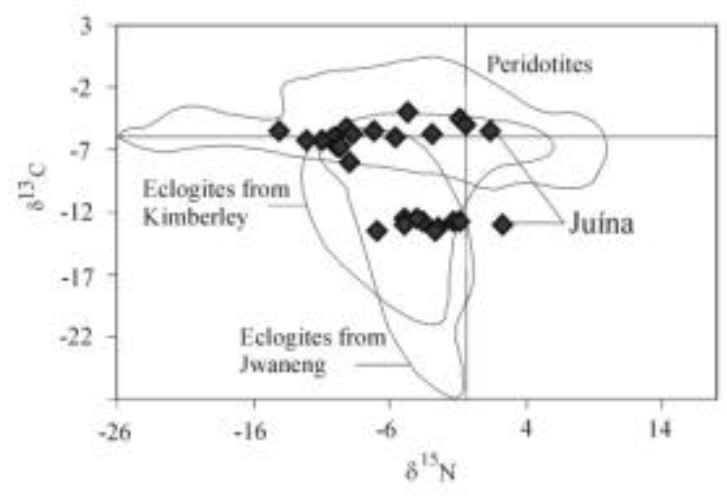

Figure 4 - $\ddot{a}^{13} \mathrm{C}$ - $\ddot{a}^{15} \mathrm{~N}$ Co-variation for diamond occurrences. Fields for worlwide peridotite and for eclogites from Kimberley and Jwaneng are from Cartigny et al. (1998a and 1998b). Filled symbols are Type I diamonds from this study. The vertical line is the atmospheric $\delta^{15} \mathrm{~N}$ value (Mariotti $1983)$ and the horizontal line is the primordial composition for $\delta^{13} \mathrm{C}(-4.6 \%$ ).

As observed for deep diamond assemblages, the Juina Kimberlite Province contains elevated percentage of Type II diamonds (82\%) and highly aggregated Type I stones, indicating high temperature and/or long time of mantle residence. Considering the rarity of Type II diamonds in the upper mantle and the high aggregation of $\mathrm{N}$ in Type I diamonds, we suggest that the majority part of diamonds investigated here were originated in the LM and TZ.

The abundance of Type II diamonds in the TZ and LM suggests the existence of particular conditions that avoid $\mathrm{N}$ incorporation by diamonds. The formation of osbornite (TiN) and sinoite $\left(\mathrm{Si}_{2} \mathrm{~N}_{2} \mathrm{O}\right)$ and/or $\mathrm{N}$ exsolved in silicates are suggested in the literature. An alternative explanation for $\mathrm{N}$-free diamond formation 
is the elevated temperature of $\mathrm{TZ}$ and LM. This is suggested here based on diamond synthesis experiments performed by Burns et al. (1999) that showed the decrease of $\mathrm{N}$ incorporation by diamond as the $\mathrm{N}$ solubility of the environment increases, which, on its turn, increases with temperature.

The light composition of $\ddot{a}^{13} \mathrm{C}$ for Type II diamonds, down to $-26,3 \%$, may indicate that the $\mathrm{TZ}$ bellow the SW Amazon Craton was influenced by re-cycled carbon, which would be in accordance with subductions that originated the Rondoniana Santo Ignácio and Sunsás terrains between 1.5 to $1.0 \mathrm{Ga}$ at the SW border of the Amazon Craton.

\section{ACKNOWLEDGEMENT}

The authors are greatly thankful to RTDM Ltd. and De Beers Brasil Ltd. for providing the diamonds for this study, to Gergely Szabo from the University of São Paulo and Jamies Rougvie from the Smithsonian Institution for CL images, to Richards Wysoczanski from the Smithsonian Institution and to Lisa Miller and Zhenxian Liu from the Brookhaven National Labratory for IR measurements.

\section{REFERENCES}

Araujo D.P. 2002. Mineralogia dos diamantes da Provincia Kimberlitica de Juina. Ph.D. thesis. University of Brasília. Brasília, Brazil (in portuguese).

Bizzi L.A. 1993. Mesozoic alkaline volcanism and mantle evolution of the southwestern São Francisco Craton, Brazil. Ph.D. Thesis. Cape Town, South Africa.

Burns R. C., Hansena a, J. O., Spitsa R. A., Sibandaa M., Welbournb C. M., Welcha D. L. 1999. Growth of high purity large synthetic diamond crystals. Diamond and Related Materials 8(8-9):1433-1437.

Cartigny P., Harris J.W., Javoy M. 1998a. Eclogitic diamond formation at Jwaneng: No room for a recycled component. Science, 280: 1421-1424.

Cartigny P., Harris J.W., Phillips D., Boyd S.R., Javoy M. 1998b. Subducted-related diamonds? - The evidence for a mantle derived-origin from coupled $\ddot{a}^{13} \mathrm{C}-\ddot{a}^{15} \mathrm{~N}$ determinations. Chem. Geol, 147:147-159.

Cartigny P., Harris J.W., Javoy M. 1999. Eclogitic, peridotitic and metomorphic diamonds and the problems of carbon recycling - The case of Orapa (Botswana). In: IKC,
International Kimberlite Conference, 7. Proceedings. J.J. Gurney, J.L. Gurney, M.D. Pascoe, and S.H. Richardson (eds.).V1: 117-124.

Deines P. Harris J.W., Gurney J.J. 1991. The carbon isotopic composition and nitrogen content of lithospheric and asthenospheric diamonds from the Jagersfontein and Koffiefontein kimberlite, South Africa. Geochim. Cosmoch. Acta. 55(9):2615-2625.

Davies R.M., Griffin W.L., Pearson N.J., Andrew A.S., Doyle B.J., O'Reilly S.Y. 1999. Diamonds from the deep: Pipe DO-27, Slave Craton, Canada. In: IKC, International Kimberlite Conference, 7. Proceedings. J.J. Gurney, J.L. Gurney, M.D. Pascoe, and S.H. Richardson (eds.).V1:148155

Harte B., Harris J.W. 1994. Lower mantle mineral associations preserved in diamonds. Mineral. Mag. 58A : 384 385 .

Hauri E.H., Pearson D.G., Bulanova G.P., Milledge H.J. 1999. Microscale variations in $\mathrm{C}$ and $\mathrm{N}$ isotopes within mantle diamonds revealed by SIMS. In: IKC, International Kimberlite Conference, 7. Proceedings. J.J. Gurney, J.L. Gurney, M.D. Pascoe, and S.H. Richardson (eds.).V1:341347.

Heaman L., Teixeira N.A., Gobbo L., Gaspar J.C. (1998) U$\mathrm{Pb}$ zircon ages for kimberlites from the Juina and Paranatinga provinces, Brazil. Exp. Abstracts. VII IKC:322-324.

Hutchison M.T. 1997. Constitution of the deep transition zone and lower mantle shown by diamonds and their inclusions. Ph.D. thesis. Edinburgh, UK.

Kaminsky F.V., Zakharchenko O.D., Davies R., Griffin W.L., Khachatryan-Blinova G.K., Shiryaev A.A. 2001. Super deep diamonds from the Juina area, Mato Grosso State, Brazil. Contrib. Mineral. petrol.140:734-753.

Mariotti A. (1983) Atmospheric nitrogen is a reliable standard for natural $15 \mathrm{~N}$ abundance measurements. Nature, 303:685-687.

Tassinari C.C.G., Bettencourt J.S., Geraldes M.C., Macambira M.J.B., Lafon J.M. 2000. The Amazonian Craton. In: Tectonic Evolution of South America. (ed. U.G. Cordani, E.J. Milani, A. Thomaz Filho, D.A. Campos) p.4195

Wilding M.C., Harte B., Harris J.W. 1991. Evidence for a deep origin for São Luiz diamonds. In: IKC, International Kimberlite Conference, 5. Extended Abstracts:456-458. 
Contact: DP Araújo, deboraparaujo@ @otmail.com.

JC Gaspar, Instituto de Geociências, Universidade de Brasília,

Brasília-DF, Brazil 70910-900. gasp@unb.br 